\title{
Longterm quiescent cells in the aged human subventricular neurogenic system specifically express GFAP- $\delta$
}

Simone A. van den Berge, ${ }^{1}$ Jinte Middeldorp, ${ }^{1} \mathrm{C}$. Eleana Zhang, ${ }^{1}$ Maurice A. Curtis, ${ }^{2,3}$ Brian W. Leonard, ${ }^{4}$ Diego Mastroeni, ${ }^{4}$ Pieter Voorn, ${ }^{5}$ Wilma D. J. van de Berg, ${ }^{5}$ Inge Huitinga ${ }^{6}$ and Elly M. Hol ${ }^{1}$

${ }^{1}$ Astrocyte Biology \& Neurodegeneration, Netherlands Institute for Neuroscience (NIN), an institute of the Royal Netherlands Academy of Sciences, Amsterdam, The Netherlands

${ }^{2}$ Department of Anatomy with Radiology, Faculty of Medical and Health Sciences, The University of Auckland, Auckland, New Zealand

${ }^{3}$ Center for Brain Repair and Rehabilitation at Sahlgrenska

Academy, Göteborg, Sweden

${ }^{4}$ Sun Health Research Institute, Sun City, AZ, USA

${ }^{5}$ Department of Anatomy and Neurosciences, Neuroscience Campus Amsterdam, VUMC, Amsterdam, Netherlands

${ }^{6}$ Neuroimmunology, NIN, an institute of the Royal Netherlands Academy of Sciences, Amsterdam, The Netherlands

\section{Summary}

A main neurogenic niche in the adult human brain is the subventricular zone (SVZ). Recent data suggest that the progenitors that are born in the human SVZ migrate via the rostral migratory stream (RMS) towards the olfactory bulb (OB), similar to what has been observed in other mammals. A subpopulation of astrocytes in the SVZ specifically expresses an assembly-compromised isoform of the intermediate filament protein glial fibrillary acidic protein (GFAP- $\delta$ ). To further define the phenotype of these GFAP- $\delta$ expressing cells and to determine whether these cells are present throughout the human subventricular neurogenic system, we analysed SVZ, RMS and OB sections of 14 aged brain donors (ages 74-93). GFAP- $\delta$ was expressed in the SVZ along the ventricle, in the RMS and in the OB. The GFAP- $\delta$ cells in the SVZ co-expressed the neural stem cell (NSC) marker nestin and the cell proliferation markers proliferating cell nuclear antigen (PCNA) and $M c m 2$. Furthermore, BrdU retention was found in GFAP- $\delta$ positive cells in the SVZ. In the RMS, GFAP- $\delta$ was expressed in the glial net surrounding the neuroblasts. In the OB, GFAP- $\delta$ positive cells co-expressed PCNA. We also

\section{Correspondence}

Elly M. Hol \& Simone A. van den Berge, Netherlands Institute for Neuroscience, Meibergdreef 47, 1105 BA Amsterdam, the Netherlands. Tel.: +31 20 5665500; fax: +31 20 5666121; e-mail: e.hol@nin.knaw.nl, s.van.den. berge@nin.knaw.nl

Accepted for publication 25 January 2010 showed that GFAP- $\delta$ cells are present in neurosphere cultures that were derived from SVZ precursors, isolated postmortem from four brain donors (ages 63-91). Taken together, our findings show that GFAP- $\delta$ is expressed in an astrocytic subpopulation in the SVZ, the RMS and the OB. Importantly, we provide the first evidence that GFAP$\delta$ is specifically expressed in longterm quiescent cells in the human SVZ, which are reminiscent of NSCs.

Key words: adult neural stem cells; astrocytes; subventricular zone; rostral migratory stream; olfactory bulb; aging brain.

\section{Introduction}

The adult human brain contains two regions where continuous neurogenesis takes place, i.e. the subventricular zone (SVZ) (Sanai et al., 2004; Quinones-Hinojosa et al., 2006) and the subgranular zone in the hippocampal dentate gyrus (Eriksson et al., 1998; Roy et al., 2000). In particular, the SVZ maintains a level of plasticity into adulthood and can respond to certain neurological conditions, such as stroke and Huntington's disease, by increasing the number of neuron forming precursor cells that can potentially replace damaged neurons. In animal models of brain trauma, disease and stroke, the SVZ responds by producing new precursor cells, which migrate to the damaged areas and form new regionally specific neurons (Parent et al., 2002; Cooper \& Isacson, 2004). In the human brain, a similar response seems to occur after ischaemia (Macas et al., 2006). The SVZ can react in this way because it is situated close to the striatum, which is affected in Parkinson's disease and Huntington's disease and it receives nutrients from the cerebrospinal fluid in the lateral ventricle (for review, see (Curtis et al., 2007a)). One of the key questions that remain to be answered is which cells in the SVZ are responsible for ultimately producing the new cells in the human SVZ.

The composition of the human SVZ is different from that of the more studied rodent species because of the presence of a hypocellular gap between the ependymal layer and the dense astrocytic ribbon, the latter of which contains the neural precursors (Quinones-Hinojosa et al., 2006). There are indications that a subpopulation of astrocytes in this ribbon, the neurogenic astrocytes, proliferate in vivo and behave as multipotent precursor cells in vitro (Sanai et al., 2004), implying that SVZ astrocytes of the adult human brain indeed are neural stem cells (NSCs). Within the SVZ, three major cell types exist, one of which is the neurogenic astrocyte known as B-cell (Doetsch et al., 1997), which is a slowly proliferating cell that asymmetrically divides to 
form a pool of fast-dividing neural progenitor cells, the C-cells. Type C-cells in turn differentiate into type A-cells, called neuroblasts, which migrate through the rostral migratory stream (RMS) into the olfactory bulb (OB), where they differentiate into new interneurons (Curtis et al., 2007b). The existence of an RMS in the human brain, long thought absent, was recently described by Curtis et al., (2007b). Recently, we have shown that NSCs are still present in the SVZ of elderly subjects, including cases with neurodegenerative diseases, such as Alzheimer's disease (Leonard et al., 2009).

NSCs express certain intermediate filament (IF) proteins, and some reports claim the specificity of these for labelling NSCs. IFs are highly versatile cytoskeletal structures that have a major function in cell signalling and migration (Lepekhin et al., 2001; Pallari \& Eriksson, 2006; Herrmann et al., 2007). One IF expressed in NSCs is nestin, widely regarded as specific for NSCS (for review, see (Gilyarov, 2008)), but conflicting reports reveal nestin expression in both reactive and mature astrocytes (Lin et al., 1995; Gu et al., 2002). Our laboratory has been interested in specific IF expression as they relate to NSCS. To this end, our previous work has revealed that SVZ astrocytes in the human brain express the IF protein glial fibrillary acidic protein $\delta$ (GFAP- $\delta$ ) (Roelofs et al., 2005), one of the seven splice variants of GFAP (Hol et al., 2003; Quinlan et al., 2007), the main IF protein in astrocytes (Eng et al., 2000)). Moreover, we recently have described that GFAP- $\delta$ is expressed in radial glia and SVZ progenitors of the human foetal brain (Middeldorp et al., 2010), substantiating our earlier findings that this specific GFAP isoform is a marker for NSC. GFAP- $\delta$ (also named GFAP- $\varepsilon$ (Nielsen et al., 2002)) has a unique 41 amino acid carboxy-terminus. This unique tail domain endows the protein with several properties distinct from GFAP- $\alpha$, which are likely to have important functional consequences for the IF network formed in the SVZ astrocytes. Firstly, GFAP- $\delta$ is an assembly-compromised form of GFAP (Nielsen et al., 2002; Roelofs et al., 2005; Perng et al., 2008) and its presence in the IF network changes the composition of the IF network and its associated proteins, such as $\alpha \mathrm{B}$-crystallin (Perng et al., 2008). The network can tolerate up to $10 \%$ of the GFAP- $\delta$ isoform, which is approximately the amount found in the central nervous system (Perng et al., 2008). A second property of GFAP- $\delta$ is its ability to interact with presenilins (Nielsen et al., 2002), which are essential partners in the gamma-secretase complex. This complex cleaves the transmembrane proteins Notch and amyloid precursor protein (APP) inside the membrane region and therefore is critical for Notch and APP signalling (Selkoe \& Kopan, 2003). Notch signalling is required for maintenance of NSC populations in both the developing and adult brain (Alexson et al., 2006), and Notch1 expression can be found in SVZ astrocytes and neuroblasts in the adult rodent brain (Givogri et al., 2006). Thirdly and finally, the induced expression of GFAP- $\delta$ in vitro results in an increased phosphorylation of Jnk (Perng et al., 2008). In the developing brain, Jnk is involved in NSC proliferation (Wang et al., 2007), migration (Mizuno et al., 2005), and differentiation (Kim et al., 2007).
Localization of GFAP- $\delta$ and its ability to modulate signalling pathways important for NSCs suggest that GFAP- $\delta$ is expressed by NSCs in the adult SVZ. Here, we have studied the expression of GFAP- $\delta$ in the SVZ, RMS and OB in the adult human brain. We provide evidence that the GFAP- $\delta$ expressing cells may indeed be quiescent adult NSCs, as they are present throughout the human adult neurogenic system, in a subpopulation of proliferating astrocytes in the SVZ, and in neurosphere cultures isolated from postmortem adult human SVZ material.

\section{Results}

\section{GFAP- $\delta$ is robustly expressed in an astrocytic ribbon of variable width along the full length of the SVZ}

We have previously described that GFAP- $\delta$ is expressed in the SVZ along several brain structures and subpial layers of the adult human brain (Roelofs et al., 2005). In the current study, we have systematically studied its expression pattern throughout the SVZ of five aged control brains at three standardized locations (see Fig. 1A, and Experimental procedures). When staining these three areas for GFAP- $\delta$, we observed a band of immunostaining in the SVZ throughout the three sampled locations. The cells in this band often had an elongated morphology, parallel to the ependymal lining of the SVZ. The width of the immunoreactive band, which ranged from 20 to $200 \mu \mathrm{m}$ (Fig. 1B), was not constant within the three SVZ areas of one donor and showed also large variability among donors. We have performed a correlation analysis between the variability and several characteristics of the donors, such as age, sex, postmortem delay and medication used, and found no significant correlations. Figure 1C-E shows a typical example of the strong variability of the thickness of the band of GFAP- $\delta$ expressing astrocytes throughout the SVZ of one donor. The SVZ regions of the same donor stained for all GFAP isoforms revealed many more GFAP positive cells and encompassed labelling in the caudate nucleus, SVZ and in the hypocellular gap (Fig. $1 \mathrm{~F}-\mathrm{H}$ ). These data substantiate our earlier findings that GFAP- $\delta$ is expressed in a subset of astrocytes in the SVZ, forming a ribbon. In addition, we provide a first report on the large variation in the width of the astrocytic ribbon within and between donors, and in the quantity of GFAP- $\delta$ positive cells in the SVZ.

\section{GFAP- $\delta$ is expressed in immature, proliferative SVZ astrocytes with stem cell characteristics}

To establish the specific phenotype of the cells in the astrocytic ribbon that express GFAP- $\delta$, we applied a double-immunolabelling technique using various astrocyte-specific markers in the three SVZ areas. Results of confocal analysis are shown in Fig. 2; images showing anatomical localization are shown in supplemental Fig. S1. GFAP- $\delta$ was expressed in a subpopulation of astrocytes that also expressed the astrocyte marker GFAP- $\alpha$ (Fig. 2A), as shown by clear co-localization with an antibody specific for the C-terminus of GFAP. The immature astrocyte 

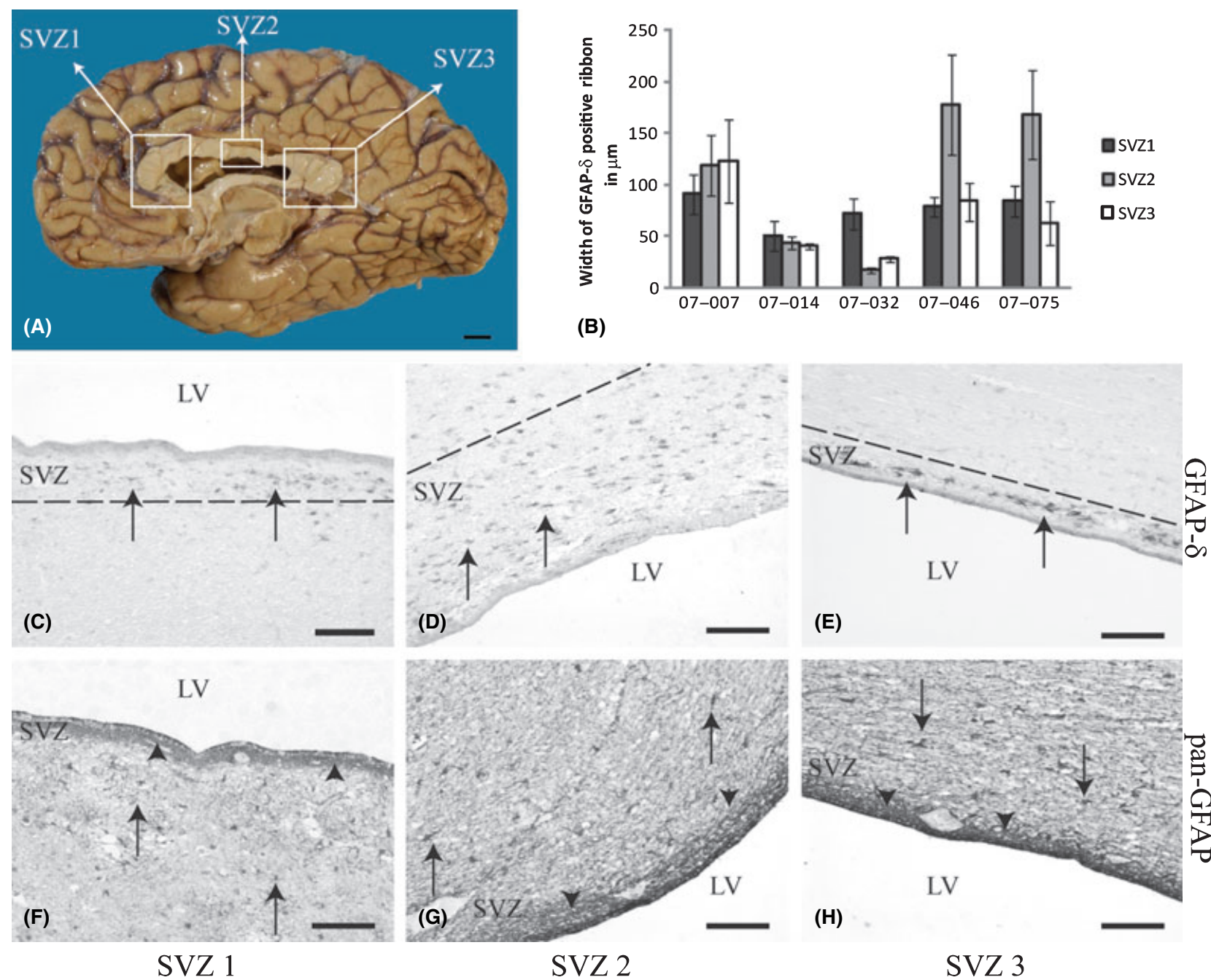

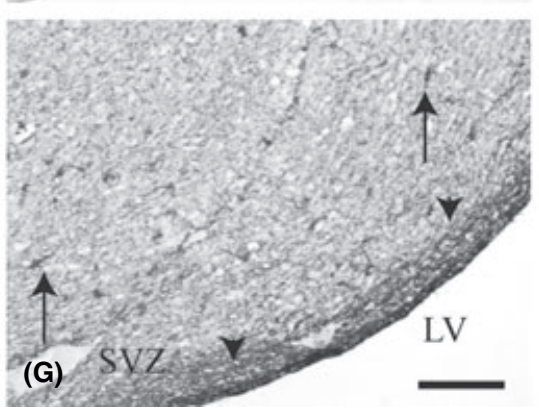

SVZ 2

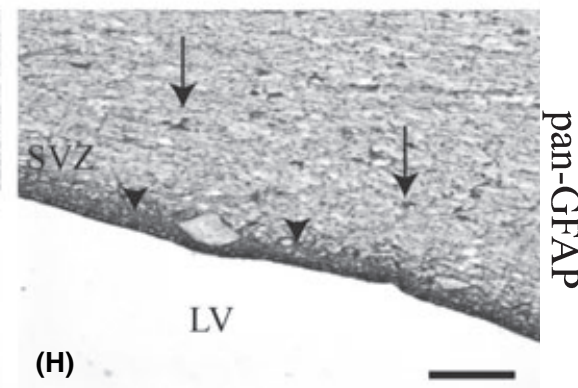

SVZ 3

Fig. 1 GFAP- $\delta$ in the aged human SVZ. (A) Schematic location of SVZ tissue samples as collected from the Netherlands Brain Bank (NBB). SVZ1 was taken out at the level of the most frontal part of the caudate nucleus; SVZ2 came from the area beneath the cingulate gyrus; SVZ3 contained the most posterior part of the lateral ventricle. (B) Quantification of the width of the GFAP- $\delta$ ribbon in frontal sections throughout the SVZ of five different donors. (C-E) Examples of GFAP- $\delta$ staining (arrows) throughout the SVZ of a control brain (NBB 07-075). F-H) pan-GFAP staining in the same SVZ areas; staining can be found in the parenchyma (arrows) and in the SVZ (arrowheads). Scale bars indicate $1 \mathrm{~cm}$ in A), $100 \mu \mathrm{m}$ in $\mathrm{C}-\mathrm{H}$ ); data in (B) are represented as mean values \pm SEM, $n=5 \mathrm{measurements} \mathrm{per} \mathrm{SVZ} \mathrm{region;}$ $\mathrm{LV}=$ lateral ventricle; dashed line indicates border of GFAP- $\delta$ positive ribbon. Picture (A) Courtesy of NBB and photo service Pathology department VUMC, NL.

marker vimentin, an IF protein, also co-localized with GFAP- $\delta$ (Fig. 2B). To the contrary, the calcium binding protein S100B, and the enzyme glutamine synthetase (GS), a marker of fully differentiated astrocytes, were not expressed in GFAP- $\delta$ cells. S100B was expressed in a distinct cell population in the SVZ (Fig. 2C), most likely representing more mature niche astrocytes; expression of GS was only found in cells of the parenchyma and not in the SVZ (Fig. 2D). GFAP- $\delta$ was not expressed by postmitotic neurons, as was shown by the absence of co-localization with NeuN (data not shown).

To investigate whether GFAP- $\delta$ cells in the aged SVZ are NSCS, we studied the co-expression of GFAP- $\delta$ with proliferation markers and markers for NSCs. Results of confocal analysis are shown in Fig. 3; images showing anatomical localization are shown in supplemental Fig. S2. We found that all GFAP- $\delta$ positive cells also express the proliferation marker proliferating cell nuclear antigen (PCNA; Fig. 3A), the mitosis marker minichromosome maintenance complex component 2 ( $\mathrm{Mcm} 2$; Fig. $3 \mathrm{~B}$ ) and the transcription factor Sox2 (Fig. 3C). The latter marker showed staining in both cell nuclei and in cytoplasm, which has been described before for the human brain (Baer et al., 2007). The phosphorylated form of the histone $\mathrm{H} 3$ protein $(\mathrm{pHH} 3$ ) was not expressed in GFAP- $\delta$ positive cells (Fig. 3D), and also no doublelabelling with Ki-67, another proliferation marker, was seen (Fig. 3E); in fact very few $\mathrm{pHH} 3$ and Ki-67 positive cells were present in the SVZ, which is in agreement with earlier reports (Kukekov et al., 1999). Attempts to co-localize GFAP- $\delta$ with CD133 were unsuccessful in this paraffin-embedded material.

We also studied co-localization with the thymidine analogue BrdU, which labels dividing cells in the S-phase. In one of the brains treated with BrdU, many BrdU-positive nuclei were found in the SVZ near the caudate nucleus, many of which were 

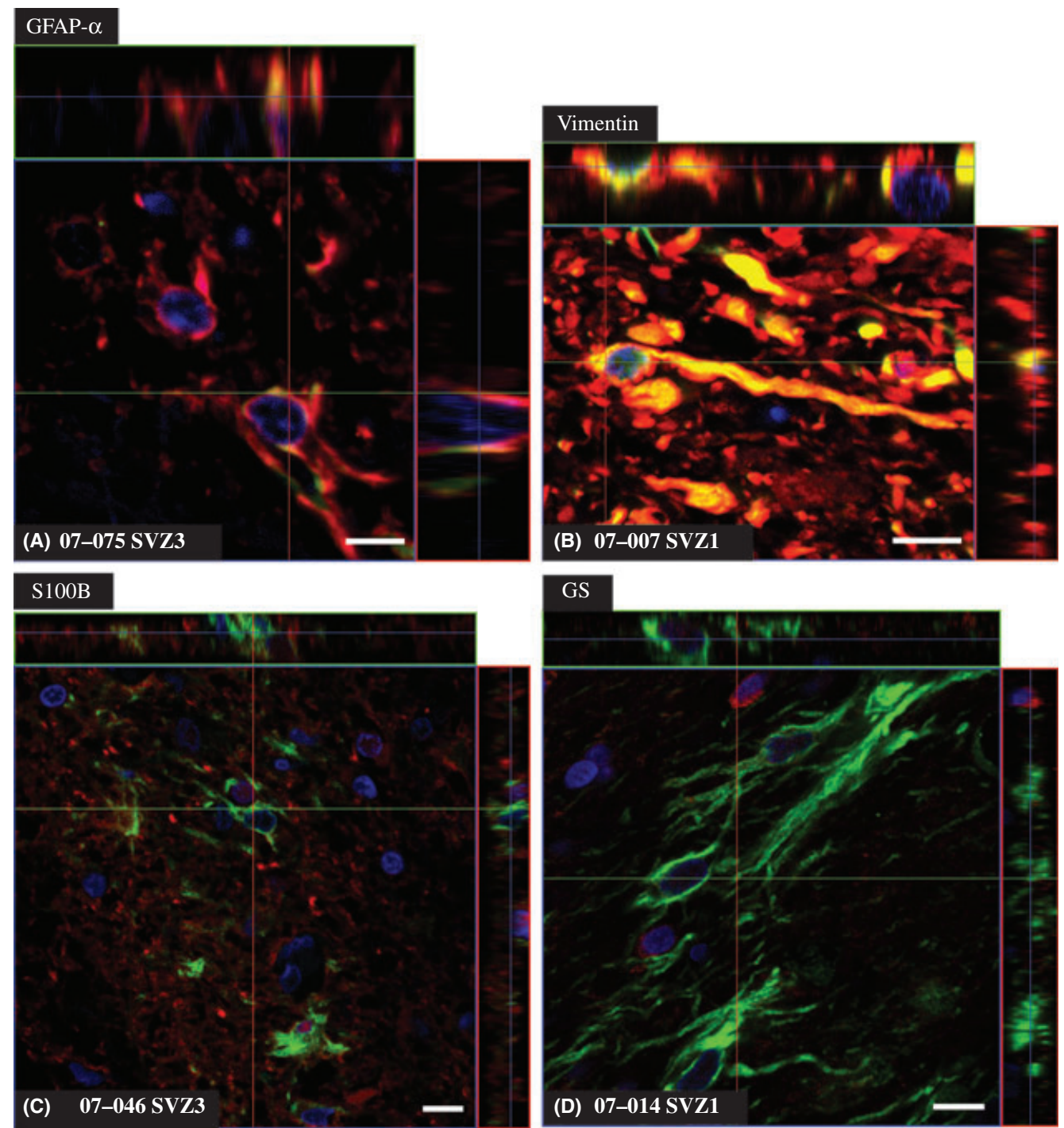

Fig. 2 Fluorescent double immunostaining of GFAP- $\delta$ with astrocyte markers in the SVZ. GFAP- $\delta$ staining is shown in green, the respective astrocyte markers in red. (A) GFAP- $\delta$ is expressed in a subpopulation of GFAP- $\alpha$ positive cells. (B) Vimentin expression was found mainly in the SVZ, in all GFAP- $\delta$ positive cells. (C) S100B is expressed throughout the tissue, in the SVZ there is no co-expression with GFAP- $\delta$. (D) Glutamine synthetase was expressed only in the parenchyma, not in the SVZ. Blue staining is Topro staining for cell nuclei; scale bars indicate $5 \mu \mathrm{m}$ in A and B; $10 \mu \mathrm{m}$ in C and D; individual NBB numbers of the cases are indicated in the left bottom corner.

GFAP- $\delta$-positive (Fig. 3F). Besides the SVZ astrocytes, many fibres around BrdU positive ependymal cells were GFAP- $\delta$ positive. Deeper into the brain parenchyma, BrdU positive nuclei were scarce. In the second human BrdU case, much less BrdU labelling was found, and there was a corresponding reduction in the number of double-positive cells. In the second BrdU case, the time from BrdU injection to postmortem examination was protracted compared to the first case. Our data so far demonstrate that GFAP- $\delta$ positive cells are proliferative, which is one indication that these cells are indeed NSCs.

Subsequently, we studied whether the cells co-express markers for different stages of stem cell differentiation. We observed considerable co-expression between GFAP- $\delta$ and nestin (B-cells: Fig. $3 G$ ). However, this pattern was variable throughout the
SVZ; we observed regions with almost complete overlap between the stainings, as well as locations with minimal overlap. We also observed that GFAP- $\delta$ positive cells only rarely expressed the C-cell marker EGF-R (Fig. $3 \mathrm{H}$ ) or the A-cell marker $\beta$-III-tubulin (Fig. 3I). Attempts to co-localize GFAP- $\delta$ with PSANCAM or DCX, using different antibodies (as mentioned in supplementary Table S1), were unsuccessful.

\section{GFAP- $\delta$ is expressed in the glial net surrounding the RMS}

In 2007, the first details emerged about the existence of the RMS in the human brain, although organized differently than in mice (Curtis et al., 2007b). Furthermore, Alonso et al. showed 

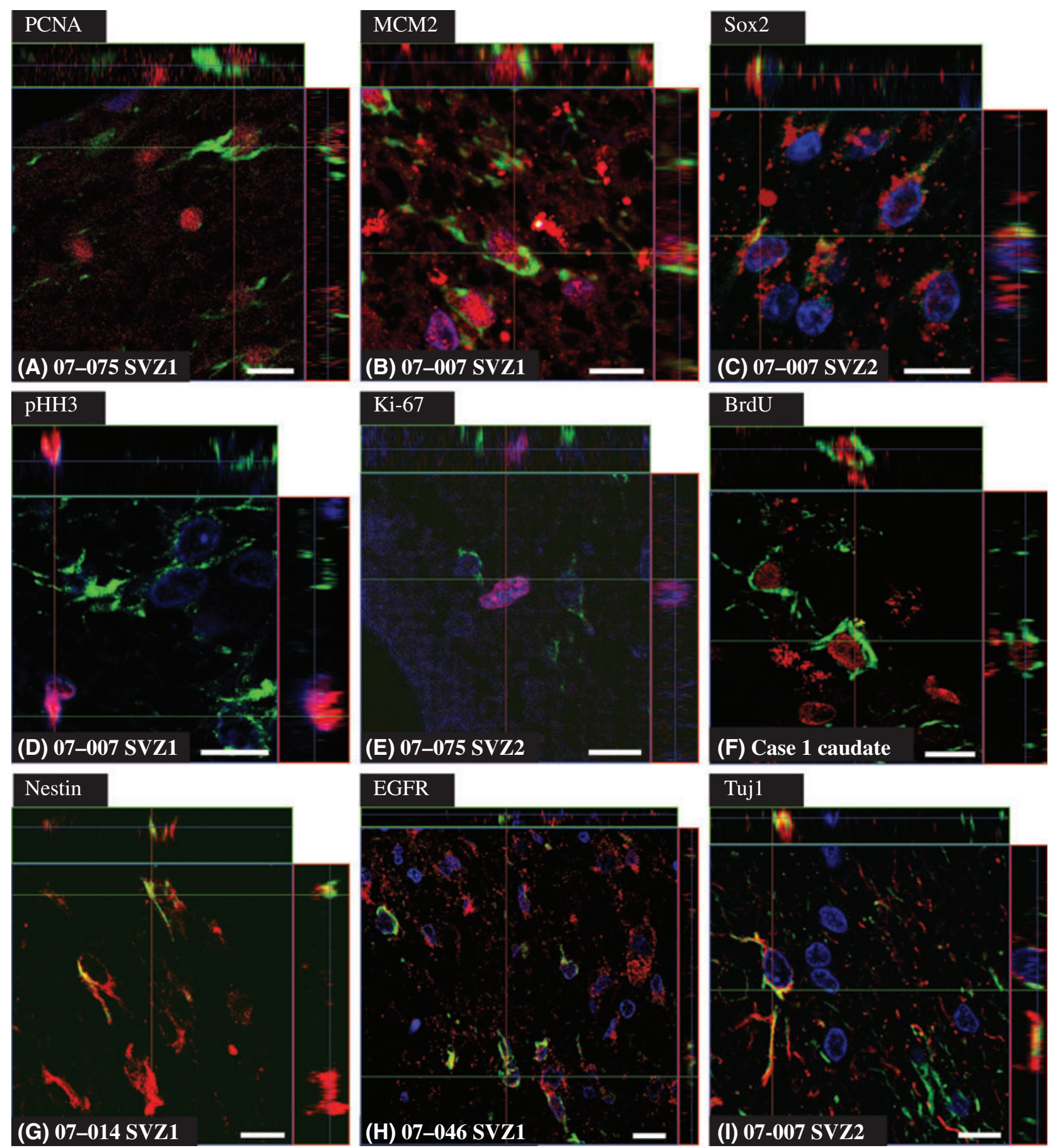

Fig. 3 Fluorescent double immunostaining of GFAP- $\delta$ (green) with proliferation and stem cell markers (red) in the SVZ of different control donors. (A) proliferating cell nuclear antigen (PCNA) expression is high in the SVZ; most GFAP- $\delta$ positive cells express PCNA. (B) Most GFAP- $\delta$ positive cells are Mcm2 positive. (C) Sox2 is expressed in nuclei and cytoplasm of GFAP- $\delta$ positive cells. (D) pHH3 positive cells were extremely rare and did not express GFAP- $\delta$. (E) Ki-67 positive cells could only be found occasionally and were not GFAP- $\delta$ positive. (F) BrdU labelling was found in many GFAP- $\delta$ positive cells. (G) In double immunostainings for nestin and GFAP- $\delta$, cells could be found with both proteins and with the single proteins. (H) EGF-R was hardly ever found in GFAP- $\delta$ expressing cells. (I) Rarely, single cells could be found expressing GFAP- $\delta$ and $\beta$-III-tubulin. Blue staining is Topro staining for cell nuclei; scale bars indicate $10 \mu m$ in all; individual NBB numbers of the cases are indicated in the left bottom corner.

that astrocytes in the rodent RMS are neurogenic (Alonso et al., 2008). Therefore, we examined the aged human RMS for the presence of GFAP- $\delta$. Indeed, we found GFAP- $\delta$ to be highly expressed throughout the RMS (Fig. 4). In fact, GFAP- $\delta$ is a very reliable and robust marker of the RMS in the human brain. In sagittal sections taken from the RMS, the dorsal and rostral 

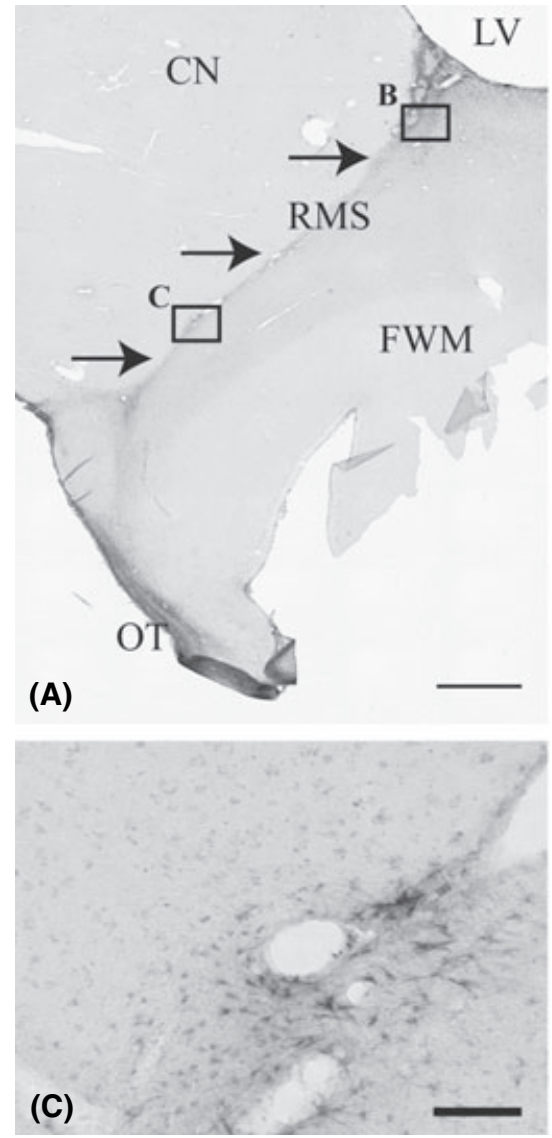
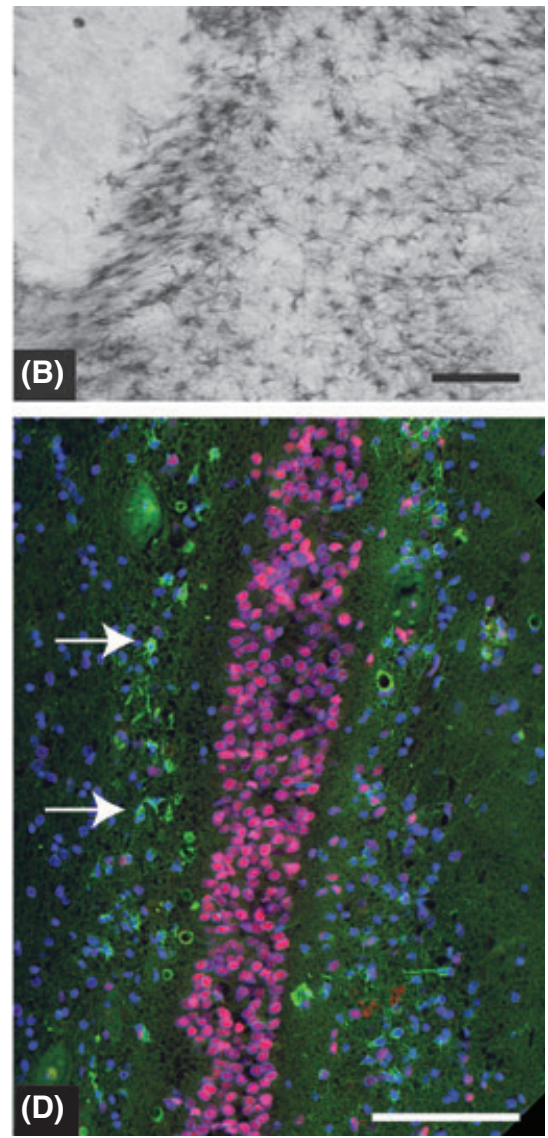

Fig. 4 GFAP- $\delta$ expression in the RMS. (A) Overview of the RMS (arrows) of case ANW228 from the SVZ to the OT in a sagittal section. Boxed areas are enlarged in (B) and (C). (D) Fluorescent immunostaining for proliferating cell nuclear antigen (red) and GFAP- $\delta$ (green) (arrows) in a frontal section of the dorsal limb of the RMS of case NBB 06-002. Blue staining is Hoechst staining for cell nuclei. $\mathrm{LV}=$ lateral ventricle, $\mathrm{CN}=$ caudate nucleus, FWM = frontal white matter,

$\mathrm{RMS}=$ rostral migratory stream, OT = olfactory tract; scale bars indicate $2 \mathrm{~mm}$ in (A), $0.1 \mathrm{~mm}$ in $B-D$. limbs of the RMS were visible in a number of sections (Fig. 4A$C)$. The dorsal limb of the RMS contained a broad band of GFAP$\delta$ immunoreactive stellate-shaped cells with cell bodies that were about 8-10 $\mu \mathrm{m}$ in diameter and had many long processes. Fewer GFAP- $\delta$ immunoreactive cells were found in the rostral limb of the RMS. There was large variation in the number of GFAP- $\delta$ immunoreactive cells in the RMS within and between donors.

In frontal sections from the striatum, which we studied for different purposes, the dorsal limb of the RMS was visible. In these sections, we observed that in double immunostaining of GFAP- $\delta$ with PCNA, PCNA was highly expressed in the centre of the stream of the RMS, whereas GFAP- $\delta$ positive astrocytes were predominantly found at the border of this stream (Fig. 4D). No co-localization was found between GFAP- $\delta$ and PCNA in the dorsal limb of the RMS (Fig. 4D).

\section{GFAP- $\delta$ is expressed in proliferative cells in the olfactory bulb}

The $O B$ and olfactory tract (OT) were also highly enriched in GFAP- $\delta$ positive cells (Fig. 5). In the centre of the OT, the GFAP- $\delta$ positive cells seemed to be organized in streams. Most GFAP- $\delta$ positive cells were however located in the outer layers of the OT (Fig. 5B). In the OB, GFAP- $\delta$ positive cells were primarily found in the olfactory nerve layer and glomerular layer (Fig. 5C and D). Few cells were also localized within the external plexiform layer and granule cell layer. Double-labelling of GFAP- $\delta$ with PCNA in the $\mathrm{OB}$ (Fig. 5E and supplemental Fig. S3E) showed that the GFAP- $\delta$ cells were proliferative. As the cells were negative for $\beta$-III-tubulin (Fig. 5F and supplemental Fig. S3F), we conclude that the GFAP- $\delta$ positive cells were not neuroblasts. In contrast to the SVZ, we very rarely observed co-expression of vimentin and GFAP- $\delta$ (Fig. $5 G$ and supplemental Fig. S3G).

\section{GFAP- $\delta$ is expressed in postmortem human adult neurospheres}

To obtain further evidence that GFAP- $\delta$ is expressed in adult NSCs, we aimed at determining whether GFAP- $\delta$ is expressed in neurospheres derived from the SVZ of human adult brain. Although the neurosphere assay has some limitations (Reynolds \& Rietze, 2005), it has long been used to assess whether a particular area of the CNS harbours stem cells. We were able to culture neurospheres from postmortem adult human material using a protocol we described recently (Leonard et al., 2009) (Fig. 6A). We isolated NSCs from each donor that came to autopsy and this was successful for $80 \%$ of the cases. As previously described, we could obtain neurospheres (Fig. 6A) from elderly donors with and without neurodegenerative diseases. 

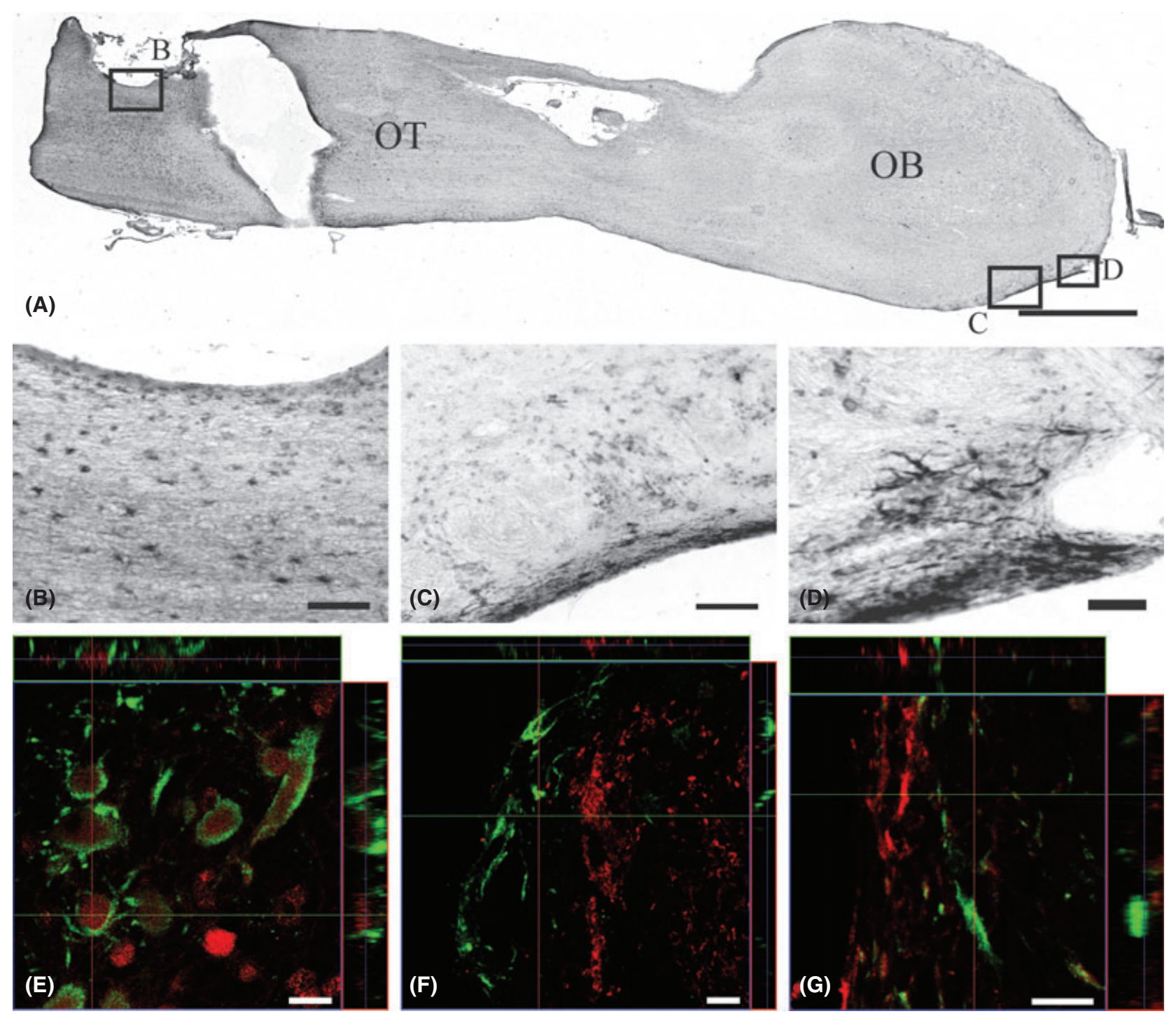

Fig. 5 GFAP- $\delta$ expression in the olfactory bulb and tract. (A) Overview of the olfactory bulb (OB) and part of the olfactory tract (OT) of a control donor (NBB 06080), stained for GFAP- $\delta$. Boxed areas are enlarged in (B) for the OT and in (C) and (D) for the glomerular layer of the OB. (E) Fluorescent immunostaining of proliferating cell nuclear antigen (PCNA) (red) and GFAP- $\delta$ (green) in the glomerular layer of the OB (NBB 05-083). PCNA was expressed throughout the glomerular layer; co-expression with GFAP- $\delta$ was observed in many cells. (F) Fluorescent immunostaining of $\beta$-Ill-tubulin (red) and GFAP- $\delta$ (green) in the glomerular layer of the OB (NBB 07-014). No co-expression of these proteins was observed. (G) Fluorescent immunostaining of vimentin (red) and GFAP- $\delta$ (green) in the glomerular layer of the OB (NBB 05-083). Co-expression of these proteins was only rarely observed. Scale bars indicate $2 \mathrm{~mm}$ in (A), $100 \mu \mathrm{m}$ in B-D, $10 \mu \mathrm{m}$ in E-F.

We found that GFAP- $\delta$ is indeed expressed in proliferative and multi-potent neurospheres. In all the cultures that we stained for GFAP- $\delta$, we could find immunoreactivity (Fig. 6B-E), overlapping the expression of GFAP- $\alpha$ (Fig. 6B), nestin (Fig. 6C), and vimentin (Fig. 6D). In the neurospheres, expression of GFAP- $\delta$ and the early neuronal marker $\beta$-III-tubulin was found mainly in distinct cell populations (Fig. 6E). Detailed analysis of co-labelling using confocal microscopy, showing co-localization with GFAP- $\alpha$, nestin and vimentin, but not $\beta$-III-tubulin can be found in supplemental Fig. S4. We confirmed the expression of GFAP$\delta$ at the RNA level by qPCR in different individual neurospheres from several donors (data not shown). We also found GFAP- $\delta$ to be expressed in newly differentiated astrocytes (Fig. 6F). This is in contrast to our findings in primary astrocyte cultures isolated from adult human brain, where it was rare to see GFAP- $\delta$ staining (unpublished data).

\section{Discussion}

In this study, we have shown that GFAP- $\delta$ expressing cells are present throughout the aged human SVZ, RMS, OT, and OB. In the SVZ and OB, GFAP- $\delta$ is expressed in a subpopulation of proliferative astrocytes that express stem cell and proliferation markers and retain BrdU longterm; and in the RMS in the glial net. We also show that GFAP- $\delta$ positive cells are present in neurospheres isolated from postmortem adult SVZ. Taken together, 

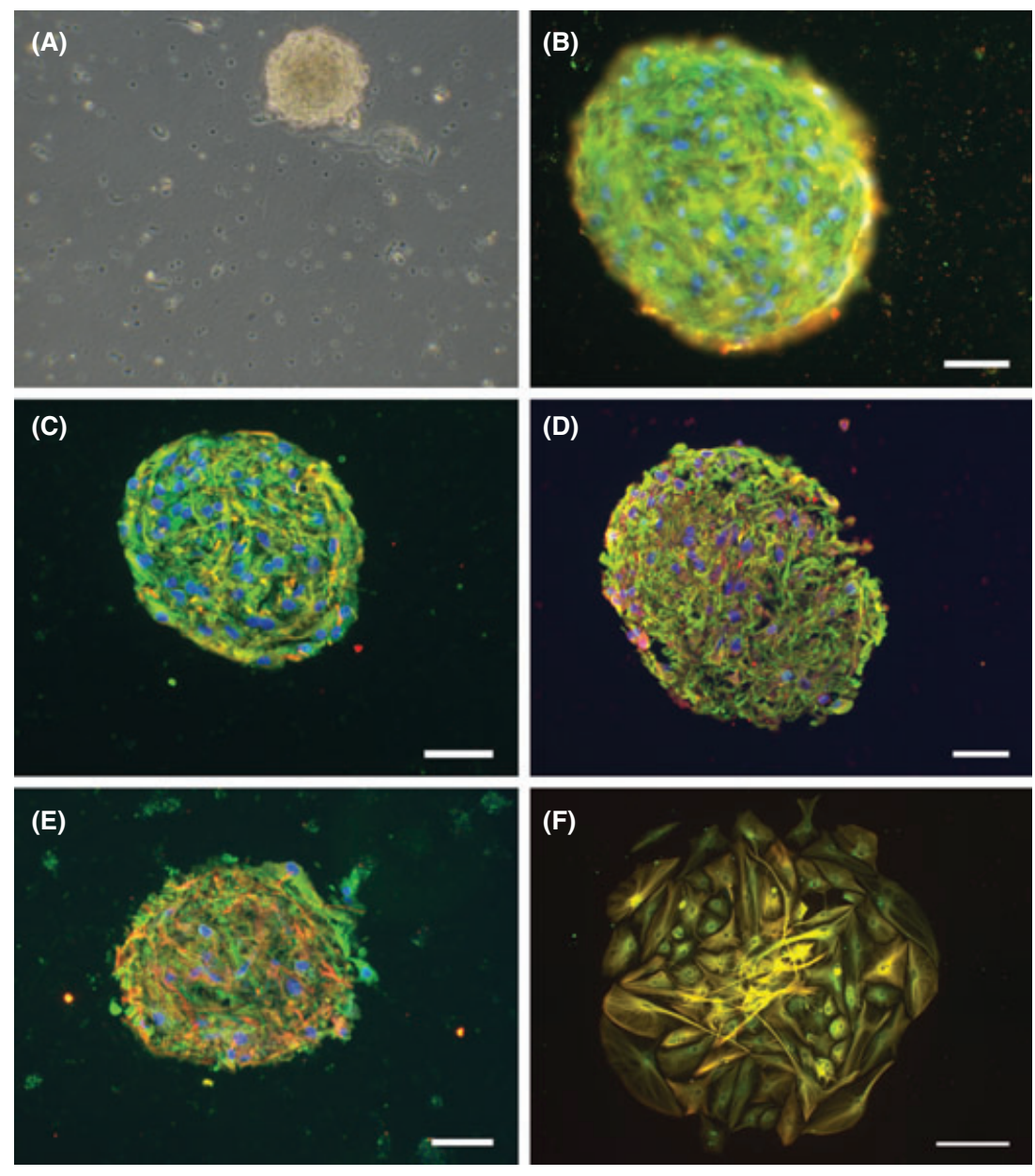

Fig. 6 GFAP- $\delta$ in neurosphere cultures from postmortem human brain. (A) Neurosphere from donor NBB 08-008 after 15 days in culture. (B)

Neurosphere cryosection from NBB 08-076, stained for GFAP- $\delta$ (green) and GFAP- $\alpha$ (red). (C) Neurosphere cryosection from NBB 08-076, stained for GFAP- $\delta$ (green) and nestin (red). (D) Neurosphere cryosection from NBB 08-078, stained for GFAP- $\delta$ (green) and vimentin (red). (E) Neurosphere cryosection from NBB 08-078, stained for GFAP- $\delta$ (green) and $\beta$-III-tubulin (red). (F) Newly differentiated astrocytes stained for panGFAP (red) and GFAP- $\delta$ (green) 14 days after differentiation (NBB 08-029). Blue staining is Hoechst staining for cell nuclei; scale bars indicate $50 \mu \mathrm{m}$ in $\mathrm{B}-\mathrm{E}, 200 \mu \mathrm{m}$ in $\mathrm{F}$. our data provide evidence that GFAP- $\delta$ expressing cells in the aged human brain are slow-cycling neurogenic astrocytes and thus NSCS.

GFAP- $\delta$ expression was found along the entire length of the SVZ of the lateral ventricles in a ribbon-like pattern. The width of this ribbon and the intensity of the expression in the brain material studied were variable within cases and between cases. It is known that there is a variation in hippocampal neurogenesis, of up to $300 \%$, between different strains of mice, implying that genetic factors influence neurogenesis considerably (Kempermann et al., 2006). Genetic differences could therefore explain the variability in the number of NSCs, and thus the number of GFAP- $\delta$ cells. Alternatively, growth factors are very important in stem cell regulation. For instance, VEGF and EGF influence GFAP-positive cells in the SVZ (Gonzalez-Perez et al., 2009; Mani et al., 2010). These and other growth factors might influence the splicing of GFAP in this region. Other than genetics and growth factors, there are many factors that influence neurogenesis (reviewed in (Zhao et al., 2008)), such as age, exercise, nicotine and a number of medications. However, the variability we observed in the GFAP- $\delta$ ribbon could not be explained by any of these factors, which were described in the medical files of the donors.
The cyto-architecture of the human SVZ has been described before (Quinones-Hinojosa et al., 2006), also with respect to the GFAP-positive astrocytic ribbon. In part, we observed a similar pattern for pan-GFAP expression, although we saw more variation in pan-GFAP staining patterns between donors. In the control donors we used, we observed a ribbon of GFAP positive cells directly adjacent to the hypocellular gap. For GFAP- $\delta$, we saw a ribbon of positive cells in the same location as described before (Roelofs et al., 2005), where fewer cells were stained for GFAP$\delta$ compared to pan-GFAP. Moreover, pan-GFAP expression could be found throughout the adjacent parenchyma, whereas GFAP- $\delta$ staining is almost undetectable in these regions. Our data suggest that GFAP- $\delta$ expression is restricted to the subpopulation of neurogenic astrocytes in the astrocytic ribbon of the SVZ.

We support this view by showing that the GFAP- $\delta$ expressing cells in the SVZ are an immature subpopulation of astrocytes that have clear NSC-like features. These cells expressed the immature astrocyte marker vimentin, and the general astrocyte marker GFAP- $\alpha$ (Eng et al., 2000). Furthermore, the GFAP- $\delta$ positive cells lacked expression of GS, a marker for fully differentiated astrocytes, and of $\mathrm{S100B}$, which in the rodent is not present in NSCs, but more mature astrocytes in the SVZ (Raponi 
et al., 2007). Co-localization of GFAP- $\delta$ with the proliferation markers PCNA, Mcm2 (Maiorano et al., 2006), and BrdU indicates that these cells are proliferative. Additionally, Sox2, a transcription factor important for the maintenance of NSCS (Graham et al., 2003), is co-expressed with GFAP- $\delta$. The retention of BrdU in GFAP- $\delta$ positive cells months after the BrdU injection suggests that these cells are slow-cycling. For the NSC marker nestin, we found a variable pattern of double-staining with GFAP- $\delta$, with numerous cells expressing both proteins, but also cells expressing either of the IF proteins. While nestin is widely used as a marker for NSCs, previous studies have shown that expression is not restricted to precursor cells and that there is little overlap with GFAP staining in the human SVZ (Gu et al., 2002). We were unable to reproduce this last finding; instead we saw considerable overlap in staining in certain regions, but this might be an illustration of the variability one might observe in nestin-GFAP patterns or a difference in the antibodies that were used for GFAP. We could not find double-labelling with the proliferation markers $\mathrm{pHH} 3$ and $\mathrm{Ki}-67$, but it must be noted that only a few cells expressing these proteins could be found, consistent with previous reports (Kukekov et al., 1999; Quinones-Hinojosa et al., 2006). This might be because of the very tight regulation of these proteins, i.e. the short half-life of Ki-67 (Mandyam et al., 2007), and the regulation of phosphorylation of the histone H3 protein (Juan et al., 1998). NSCs are slowcycling cells (Doetsch et al., 1997), and therefore it is not surprising that tightly regulated proliferation markers are only sparsely observed, or even not observed at all, in the aged human neurogenic brain areas. We only rarely observed co-expression between GFAP- $\delta$ and EGF-R, a marker for C-cells, and between GFAP- $\delta$ and $\beta$-III-tubulin, an A-cell marker, substantiating that the GFAP- $\delta$-positive astrocytes are B-cells.

In the RMS, we observed GFAP- $\delta$ staining mostly in glial cells surrounding the stream of neuroblasts. The cyto-architecture of the human RMS differs from the rodent, where there is a typical GFAP-positive glial tube (Peretto et al., 1997), which is rich in extracellular matrix components (Thomas et al., 1996). In the human brain, the neuroblasts in the RMS are surrounded by a glial 'net' or 'mesh' (Kam et al., 2009), as in the rabbit (Fasolo et al., 2002) and adult rhesus monkey brain (Pencea et al., 2001). The basic structural organization seen in the SVZ is maintained in the RMS on the side adherent to the caudate nucleus and the ependymal structure, whereas limited SVZ components are maintained on the septal or medial side of the RMS (Kam et al., 2009). From work in rodents and human material, it is clear that the RMS itself still contains precursor cells (Gritti et al., 2002; Alonso et al., 2008; Mendoza-Torreblanca et al., 2008; Kam et al., 2009), but from recent work, it appears unlikely that these are GFAP-positive in human adult brain, as no PCNA+/GFAP+ cells were found (Kam et al., 2009), which is in line with our results for PCNA and GFAP- $\delta$ in this area. Thus, in the RMS, GFAP- $\delta$ is most likely only expressed in cells of the glial net surrounding the migrating neuroblasts.

In the OB, GFAP- $\delta$ was found mostly in the glomerular layer, which is one of the regions where neuroblast migration termi- nates in rodents and where neuronal turnover takes place throughout life (Bagley et al., 2007). In the human brain, putative precursor cells were found within several areas of the $O B$, among which is the glomerular layer (Liu \& Martin, 2003; Bedard \& Parent, 2004). In our experiments in the human OB, we saw that GFAP- $\delta$ expressing cells expressed PCNA, indicating local proliferation of these cells. This makes these cells excellent candidates for the putative precursor cells described before in this area.

To investigate GFAP- $\delta$ in the process of neurogenesis more in depth, we established postmortem human neurosphere cultures, which we described recently (Leonard et al., 2009). In this in vitro model for NSCS, we found GFAP- $\delta$ expression at mRNA and protein level. GFAP- $\delta$ positive cells could be found throughout the neurospheres, co-expressing GFAP- $\alpha$, nestin and vimentin. As in the human adult SVZ, we observed that GFAP- $\delta$ and the early neuronal marker $\beta$-IIItubulin were expressed in mostly distinct cell populations. From these results, we can conclude that GFAP- $\delta$ is most likely expressed in neural precursor cells of the adult human brain, as we have found for the foetal human brain (Middeldorp et al., 2010). We are aware of the fact that the ultimate proof is still lacking, as we cannot isolate the GFAP- $\delta$ cells specifically to subject them to the neurosphere assay. For this purpose, we need to find specific cell-surface markers on GFAP- $\delta$ cells, enabling us to isolate them through FACsorting. Another observation from the neurosphere culture system was that newly differentiated astrocytes highly expressed GFAP- $\delta$, as demonstrated previously (Leonard et al., 2009), which is not the case in primary astrocytes isolated directly from postmortem human brain. This indicates that GFAP- $\delta$ is also an indicator of the differentiation state of cells.

The fact that NSCs express GFAP- $\delta$ has important functional implications. Firstly, GFAP- $\delta$ can destabilize the existing cytoskeleton of a cell (Nielsen \& Jorgensen, 2004; Roelofs et al., 2005; Perng et al., 2008), which might make a cell more flexible. This can potentially facilitate proliferation, as it is known that a cell must retract its processes, before division (Coskun et al., 2007). Also, an increased flexibility of the cytoskeleton is necessary for the migratory capacity of cells, and GFAP has been shown to have an effect on astrocyte motility (Lepekhin et al., 2001). GFAP- $\delta$ could thus alter motility of migrating cells as well, by altering the properties of the cytoskeleton. This is in part supported by the morphology of GFAP- $\delta$ cells, which are often elongated in a direction parallel to the ependymal lining of the SVZ. Another aspect of GFAP- $\delta$ expression in NSCs is its influence on cell signalling, as it can modulate Notch (Nielsen et al., 2002) and Jnk (Perng et al., 2008) signalling. An example of IF-mediated signalling is the regulation of the apoptosisinducing activity of Cdk5 by nestin (Pallari \& Eriksson, 2006), which may be the function of nestin in NSCs. A possible function of GFAP- $\delta$ in NSCs might be the modulation of Notch and/or Jnk signalling in stem cells. 
In summary, we observed GFAP- $\delta$ expression in quiescent NSCs in the adult human SVZ, in cells of the glial net of the RMS, in precursor cells in the $\mathrm{OB}$, and in newly differentiated astrocytes in vitro. These results are based on co-localization studies with several markers of neurogenesis, which have been validated extensively in rodents. For humans, results have been more ambiguous, e.g. for nestin (Gu et al., 2002) and doublecortin (Verwer et al., 2007). Therefore, all results from human studies must be interpreted with caution, but we believe that with the various markers we have used, we can state that GFAP$\delta$ is most likely a marker for NSCS/B-cells at least in the SVZ. The presence of GFAP- $\delta$ in some $C$ - and A-cells and young astrocytes could represent a transitional stage between the stem cells and their differentiated progeny. Expression of GFAP- $\delta$ in the RMS glial net suggests that it may also be important for the neurogenic niche. GFAP- $\delta$ positive cells in the OB may represent local precursor cells, but the stem cell pool in this region of the human brain has not been studied extensively yet.

Understanding the regulation of neurogenic cells is of importance with regard to neurological disorders where replacement of neurons is necessary, such as in Alzheimer's disease, Parkinson's disease, and stroke. The fact that NSCs can be found even in the aged human brain (Leonard et al., 2009) gives hope that when the precise regulation of NSCs is understood, endogenous repair by these cells may be feasible.

\section{Experimental procedures}

\section{Postmortem human brain material}

Tissue from the SVZ, RMS, and OB was obtained from the Netherlands Brain Bank (NBB; Amsterdam, The Netherlands) and the department of Anatomy and Neurosciences (ANW), VU University Medical Centre (Amsterdam, The Netherlands). The NBB and ANW perform brain autopsies with regularly short postmortem intervals, and the brain donors have given informed consent for using the tissue and for accessing the extensive neuropathological and clinical information for scientific research, in compliance with ethical and legal guidelines (Huitinga et al., 2008). Clinico-pathological information of all donors can be found in Table 1.

\section{SVZ material}

SVZ tissue for immunohistochemistry was sampled from three standardized areas in the brain as depicted in Fig. 1A. SVZ1 was dissected out at the level of the most frontal part of the caudate nucleus; SVZ2 came from the area beneath the cingulate gyrus; SVZ3 contained the most posterior part of the lateral ventricle. In SVZ1, both white and grey matter could be found aligning the SVZ, while in SVZZ and SVZ3 only white matter was seen. The donor brain tissue for this part of our

Table 1 Clinico-pathological data of the brain donors

\begin{tabular}{|c|c|c|c|c|c|c|c|c|c|}
\hline $\begin{array}{l}\text { NBB } \\
\text { number }\end{array}$ & Area studied & Sex & $\begin{array}{l}\text { Age } \\
\text { (years) }\end{array}$ & Diagnosis & $\begin{array}{l}\text { Braak stage } \\
\text { (Tau/amyloid) }\end{array}$ & $\begin{array}{l}\text { PMD } \\
\text { (h:min) }\end{array}$ & $\begin{array}{l}\mathrm{pH} \\
\mathrm{CSF}\end{array}$ & $\begin{array}{l}\text { Brain } \\
\text { weight }(g)\end{array}$ & Cause of death \\
\hline 05-019 & $\mathrm{OB}$ & $\mathrm{M}$ & 74 & Nondemented control & $3 C$ & 05:00 & 6.70 & 1125 & Bronchus carcinoma \\
\hline $05-061$ & OB & $\mathrm{F}$ & 93 & Nondemented control & 20 & $05: 50$ & - & 1145 & Cachexia \\
\hline 05-065 & OB \& RMS & $\mathrm{F}$ & 93 & Nondemented control & $1 \mathrm{~A}$ & $04: 25$ & 7.30 & 1223 & Heart failure \\
\hline 05-083 & $\mathrm{OB}$ & $\mathrm{F}$ & 85 & Nondemented control & $1 \mathrm{~B}$ & 05:00 & 6.72 & 1257 & $\begin{array}{l}\text { Multi organ failure after a } \\
\text { ruptured abdominal } \\
\text { aneurysm }\end{array}$ \\
\hline $06-080$ & OB \& RMS & $\mathrm{F}$ & 89 & Nondemented control & $2 \mathrm{~B}$ & $06: 25$ & 6.46 & 1210 & $\begin{array}{l}\text { Old age, possible ruptured } \\
\text { abdominal aneurysm }\end{array}$ \\
\hline 07-007 & SVZ \& OB & $\mathrm{M}$ & 84 & Nondemented control & $1 \mathrm{~A}$ & $05: 35$ & 6.98 & 1457 & Heart failure \\
\hline 07-014 & SVZ \& OB & M & 86 & Nondemented control & $2 \mathrm{~B}$ & 04:00 & - & 1250 & Respiratory insufficiency \\
\hline $07-032$ & SVZ & $\mathrm{F}$ & 87 & Nondemented control & 30 & $07: 20$ & 6.24 & 1140 & Cachexia and dehydration \\
\hline 07-046 & SVZ & M & 89 & Nondemented control & $1 \mathrm{~B}$ & $09: 20$ & 6.40 & 1285 & Sudden death \\
\hline 07-075 & SVZ & $\mathrm{F}$ & 82 & Nondemented control & 20 & $05: 10$ & 6.64 & 1210 & Pneumonia by hemothorax \\
\hline 06-002 & RMS & $\mathrm{F}$ & 84 & Parkinson's disease & $2 \mathrm{~B}$ & $07: 25$ & 6.85 & 1244 & Unknown \\
\hline 06-049 & RMS & $\mathrm{F}$ & 84 & Nondemented control & 10 & $04: 45$ & 6.26 & 1179 & Heart failure \\
\hline ANW228 & RMS & M & 91 & Nondemented control & $2 \mathrm{~B}$ & $<24: 00$ & - & - & Heart failure \\
\hline ANW237 & RMS & $\mathrm{M}$ & 82 & Nondemented control & $2 \mathrm{~B}$ & $<24: 00$ & - & - & Old age, dehydration \\
\hline 08-018 & Cultured SVZ & $\mathrm{F}$ & 89 & $\begin{array}{l}\text { Control with vascular } \\
\text { encephalopathy }\end{array}$ & $4 \mathrm{~B}$ & 03:30 & 6.49 & 1220 & Renal insufficiency \\
\hline 08-029 & Cultured SVZ & $\mathrm{M}$ & 84 & Alzheimer's disease & $6 \mathrm{C}$ & 08:05 & 5.95 & 1345 & Shock by hematemesis \\
\hline 08-076 & Cultured SVZ & $\mathrm{F}$ & 91 & Depression & $3 C$ & $05: 20$ & 6.53 & 1233 & $\begin{array}{l}\text { Cachexia and dehydration } \\
\text { by pneumonia and renal } \\
\text { insufficiency }\end{array}$ \\
\hline 08-078 & Cultured SVZ & M & 63 & Fronto-temporal dementia & 00 & 06:05 & 6.27 & 1327 & $\begin{array}{l}\text { Cachexia and dehydration } \\
\text { by end stage dementia }\end{array}$ \\
\hline
\end{tabular}

NBB, Netherlands Brain Bank; SVZ, subventricular zone; RMS, rostral migratory stream; OB, olfactory bulb; M, male; F, female; Braak stage is a scale for Alzheimer pathology, scoring tau (Braak and Braak, 1991) and amyloid (Thal et al., 2000) pathology; PMD, postmortem delay; CSF, cerebrospinal fluid; pH CSF indicates the agonal state of the donor (Ravid et al., 1992). 
study was selected using the following criteria: the clinical history of donors was free from any neurological disease or neuropsychiatric disorder; their brains did not have an Alzheimer Braak score higher than 3 or significant Parkinson's disease pathology. Furthermore, we excluded donors who had recently used medication that might affect neurogenesis, i.e. anti-mitotics and anti-depressants.

For neurosphere cultures, SVZ tissue was freshly isolated from the anterior horn of the SVZ. As we were restricted to the material that we could obtain from the NBB and the fact that the full neuropathological report is not available at the starting point of culturing, we included in this part of the study also patients with neurological and neuropsychiatric diseases.

\section{BrdU material}

Striatal tissue containing the SVZ was used from two donors who had received BrdU for diagnostic purposes as previously described (Eriksson et al., 1998). Case 1 was female and received BrdU 129 days before death. Case 2 was also female and died 1693 days after BrdU administration.

\section{RMS and $O B$ material}

Tissue of the human forebrain comprising the region surrounding the anterior horn of the lateral ventricle, frontal part of the caudate nucleus, gyrus rectus, substantia perforata anterior and OT, was sampled to study the RMS. Samples of the OT and OB were collected and processed for immunohistochemistry as well. The control donors for analysis of the RMS and OB were selected as for the SVZ. All tissue was immersion-fixed in phosphate-buffered $4 \%$ paraformaldehyde (PFA; $\mathrm{pH} 7.4$ ) for 4 weeks before processing.

\section{Immunostaining}

Immunostaining was performed according to a fairly standard protocol, described in full in the supplemental data. Briefly, epitope retrieval was performed in a steamer and a serum-blocking step was used before incubating with antibody (supplementary Table S1) overnight. The antibodies were visualized using biotinylated secondary antibodies, $A B C$, and $D A B$, or fluorescently labelled secondary antibodies.

\section{Human postmortem neurospheres cultures}

Neurosphere cultures were initiated as described previously (Leonard et al., 2009). The obtained microglia-poor cell pellet was taken up in serum-free medium (SFM, Neurobasal medium, 1\% B27, 0.5\% N2, 1\% Glutamax, 1\% P/S, Hepes (all Invitrogen, Carlsbad, CA, USA), $1 \%$ Ultraglutamin (Cambrex Corporation, East Rutherford, NJ, USA), $5 \mu \mathrm{gL}^{-1}$ heparin (Sigma, St. Louis, MO, USA), $20 \mathrm{ng} \mathrm{mL}^{-1}$ epidermal growth factor (EGF), and $20 \mathrm{ng} \mathrm{mL}^{-1}$ fibroblast growth factor (FGF; both Tebu-Bio, Paris, France) and plated in a 12-well plate. For differentiation, spheres were centrifuged and replated in complete Dulbecco's Modified Eagle Medium (DMEM; containing 10\% fetal calf serum, 1\% P/S, Hepes; all Invitrogen) on 12-mm polyL-lysine-coated glass coverslips.

For quantitative real-time polymerase chain reaction ( $q P C R)$, single neurospheres were isolated and taken up in $100 \mu \mathrm{L}$ Trizol (Invitrogen). RNA was isolated according to the manufacturer's protocol, with addition of glycogen to facilitate RNA precipitation. A DNase (Invitrogen) step was used to degrade genomic DNA contamination. cDNA synthesis and qPCR for GFAP- $\delta$ were performed as previously described (Perng et al., 2008).

For immunostaining, the neurospheres were fixed for $20 \mathrm{~min}$ in $3.7 \%$ formaldehyde solution (Sigma) in phosphate-buffered saline (PBS; $50 \mathrm{~mm}$ potassium phosphate, $150 \mathrm{~mm} \mathrm{NaCl}$; $\mathrm{pH}$ 7.2), after which they were embedded in TissueTek (Bayer, Leverkusen, Germany) for cryosectioning and mounted on Superfrost plus slides. Differentiated cells were fixed with formaldehyde solution in PBS on coverslips. Then, the 10- $\mu \mathrm{m}$ thick cryosections or coverslips were washed in TBS and incubated with antibodies (see supplementary Table S1) in TBS-BSA for $16-24 \mathrm{~h}$ at $4^{\circ} \mathrm{C}$. After three rinses with TBS, secondary antibodies in TBS-BSA were applied for $1 \mathrm{~h}$ at RT. Then, the sections or coverslips were rinsed three times and embedded in Mowiol.

\section{Image acquisition and analysis}

Images of single immunostainings were obtained on an AxioSkop microscope (Zeiss, Oberkochen, Germany) with Neoplanfluor objectives, using a Sony XC77 black and white camera (Sony, San Diego, CA, USA) and ImagePro software (MediaCybernetics, Bethesda, MD, USA). Images of immunofluorescent staining were obtained on an AxioPlan 2 microscope (Zeiss) with Planapochromat objectives, using an Evolution QEi black and white camera (MediaCybernetics) and ImagePro software. Confocal images were obtained on a Zeiss LSM 510 Meta Confocal Microscope (Zeiss).

For the quantification of the width of the GFAP- $\delta$ ribbon, low magnification images were taken of the whole SVZ present in one section. In this image, an area of interest (AOI) was drawn around the SVZ. In this AOI, 5 images were captured at high magnification in a randomized way. In the high magnification image, again an AOl was drawn, this time around the GFAP- $\delta$-positive area. The average width of this $\mathrm{AOI}$ was measured and used as the width of $\mathrm{GFAP}-\delta$ staining.

\section{Acknowledgments}

We thank Machiel Zandvliet, Maria Koster, Karianne Schuurman, Willem Kamphuis, Allert Jonker and Angela Ingrassia for scientific discussions and technical assistance. Postmortem human brain material was obtained from the Netherlands Brain Bank (http://www.brainbank.nl) and department of Anatomy and Neurosciences, VU University Medical Center (Amsterdam, The Netherlands) 


\section{Funding}

This work was supported by Internationaal Parkinson Fonds, Dorpmans-Wigmans Stichting, and NWO-ALW-Vici 865.09.003 to $\mathrm{EMH}$.

\section{Author contributions}

Simone van den Berge was involved in the conception and design, collection and assembly of data, data analysis and interpretation, manuscript writing, and final approval of manuscript. Jinte Middeldorp contributed to conception and design, collection and assembly of data, data analysis and interpretation, manuscript writing, and final approval of manuscript. Eleana Zhang collected analysed and interpreted data and approved the manuscript. Maurice Curtis provided study material, performed data analysis and interpretation, and approved the manuscript. Brian Leonard and Diego Mastroeni were involved in data analysis and interpretation, and the final approval of manuscript. Pieter Voorn provided study material and approved the manuscript. Wilma van de Berg was involved in provision of study material, collection of data, data analysis and interpretation, and final approval of manuscript. Inge Huitinga contributed to conception and design, data analysis and interpretation, and final approval of manuscript. Elly Hol contributed to conception and design, financial support, administrative support, data analysis and interpretation, manuscript writing, and final approval of manuscript.

\section{References}

Alexson TO, Hitoshi S, Coles BL, Bernstein A, van der Kooy D (2006) Notch signaling is required to maintain all neural stem cell populations-irrespective of spatial or temporal niche. Dev. Neurosci. 28, 34-48.

Alonso M, Ortega-Perez I, Grubb MS, Bourgeois JP, Charneau P, Lledo PM (2008) Turning astrocytes from the rostral migratory stream into neurons: a role for the olfactory sensory organ. J. Neurosci. 28, 11089-11102.

Baer K, Eriksson PS, Faull RL, Rees MI, Curtis MA (2007) Sox-2 is expressed by glial and progenitor cells and Pax- 6 is expressed by neuroblasts in the human subventricular zone. Exp. Neurol. 204, 828-831.

Bagley J, LaRocca G, Jimenez DA, Urban NN (2007) Adult neurogenesis and specific replacement of interneuron subtypes in the mouse main olfactory bulb. BMC Neurosci. 8, 92.

Bedard A, Parent A (2004) Evidence of newly generated neurons in the human olfactory bulb. Brain Res. Dev. Brain Res. 151, 159-168.

Braak H, Braak E (1991) Neuropathological stageing of Alzheimerrelated changes. Acta. Neuropathol. 82, 239-259.

Cooper O, Isacson O (2004) Intrastriatal transforming growth factor $\alpha$ delivery to a model of Parkinson's disease induces proliferation and migration of endogenous adult neural progenitor cells without differentiation into dopaminergic neurons. J. Neurosci. 24, 8924-8931.

Coskun V, Falls DL, Lane R, Czirok A, Luskin MB (2007) Subventricular zone neuronal progenitors undergo multiple divisions and retract their processes prior to each cytokinesis. Eur. J. Neurosci. 26, 593604.
Curtis MA, Faull RL, Eriksson PS (2007a) The effect of neurodegenerative diseases on the subventricular zone. Nat. Rev. Neurosci. 8, 712723.

Curtis MA, Kam M, Nannmark U, Anderson MF, Axell MZ, Wikkelso C, Holtas S, van Roon-Mom WM, Bjork-Eriksson T, Nordborg C, Frisen J, Dragunow M, Faull RL, Eriksson PS (2007b) Human neuroblasts migrate to the olfactory bulb via a lateral ventricular extension. Science 315, 1243-1249.

Doetsch F, Garcia-Verdugo JM, Alvarez-Buylla A (1997) Cellular composition and three-dimensional organization of the subventricular germinal zone in the adult mammalian brain. J. Neurosci. 17, 5046-5061.

Eng LF, Ghirnikar RS, Lee YL (2000) Glial fibrillary acidic protein: GFAP-thirty-one years (1969-2000). Neurochem. Res. 25, 14391451.

Eriksson PS, Perfilieva E, Bjork-Eriksson T, Alborn AM, Nordborg C, Peterson DA, Gage FH (1998) Neurogenesis in the adult human hippocampus. Nat. Med. 4, 1313-1317.

Fasolo A, Peretto P, Bonfanti L (2002) Cell migration in the rostral migratory stream. Chem. Senses 27, 581-582.

Gilyarov AV (2008) Nestin in central nervous system cells. Neurosci. Behav. Physiol. 38, 165-169.

Givogri Ml, de Planell M, Galbiati F, Superchi D, Gritti A, Vescovi A, de Vellis J, Bongarzone ER (2006) Notch signaling in astrocytes and neuroblasts of the adult subventricular zone in health and after cortical injury. Dev. Neurosci. 28, 81-91.

Gonzalez-Perez O, Romero-Rodriguez R, Soriano-Navarro M, GarciaVerdugo JM, Alvarez-Buylla A (2009) Epidermal growth factor induces the progeny of subventricular zone type B cells to migrate and differentiate into oligodendrocytes. Stem Cells 27, 2032-2043.

Graham V, Khudyakov J, Ellis P, Pevny L (2003) SOX2 functions to maintain neural progenitor identity. Neuron 39, 749-765.

Gritti A, Bonfanti L, Doetsch F, Caille I, Alvarez-Buylla A, Lim DA, Galli R, Verdugo JM, Herrera DG, Vescovi AL (2002) Multipotent neural stem cells reside into the rostral extension and olfactory bulb of adult rodents. J. Neurosci. 22, 437-445.

Gu H, Wang S, Messam CA, Yao Z (2002) Distribution of nestin immunoreactivity in the normal adult human forebrain. Brain Res. 943, 174-180.

Herrmann H, Bar H, Kreplak L, Strelkov SV, Aebi U (2007) Intermediate filaments: from cell architecture to nanomechanics. Nat. Rev. Mol. Cell Biol. 8, 562-573.

Hol EM, Roelofs RF, Moraal E, Sonnemans MA, Sluijs JA, Proper EA, de Graan PN, Fischer DF, van Leeuwen FW (2003) Neuronal expression of GFAP in patients with Alzheimer pathology and identification of novel GFAP splice forms. Mol. Psychiatry. 8, 786-796.

Huitinga I, Rademaker M, Klioueva N (2008) The art of brain banking in Europe: ethical, legal and practical guidelines for donor recruitment, tissue handling and tissue distribution. J. Neural Transm. 115, 1715.

Juan G, Traganos F, James WM, Ray JM, Roberge M, Sauve DM, Anderson H, Darzynkiewicz Z (1998) Histone H3 phosphorylation and expression of cyclins A and B1 measured in individual cells during their progression through $\mathrm{G} 2$ and mitosis. Cytometry 32, 71-77.

Kam M, Curtis MA, McGlashan SR, Connor B, Nannmark U, Faull RL (2009) The cellular composition and morphological organization of the rostral migratory stream in the adult human brain. J. Chem. Neuroanat. 37, 196-205.

Kempermann G, Chesler EJ, Lu L, Williams RW, Gage FH (2006) Natural variation and genetic covariance in adult hippocampal neurogenesis. Proc. Natl. Acad. Sci. USA 103, 780-785.

Kim S, Son T, Kim K, Park H, Mattson M, Lee J (2007) Interferon- $\gamma$ promotes differentiation of neural progenitor cells via the JNK pathway. Neurochem. Res. 32, 1399-1406. 
Kukekov VG, Laywell ED, Suslov O, Davies K, Scheffler B, Thomas LB, O'Brien TF, Kusakabe M, Steindler DA (1999) Multipotent stem/progenitor cells with similar properties arise from two neurogenic regions of adult human brain. Exp. Neurol. 156, 333-344.

Leonard BW, Mastroeni D, Grover A, Liu Q, Yang K, Gao M, Wu J, Pootrakul D, van den Berge SA, Hol EM, Rogers J (2009) Subventricular zone neural progenitors from rapid brain autopsies of elderly subjects with and without neurodegenerative disease. J. Comp. Neurol. 515, 269-294.

Lepekhin EA, Eliasson C, Berthold CH, Berezin V, Bock E, Pekny M (2001) Intermediate filaments regulate astrocyte motility. J. Neurochem. 79, 617-625.

Lin RCS, Matesic DF, Marvin M, McKay RDG, Brüstle O (1995) Re-expression of the intermediate filament nestin in reactive astrocytes. Neurobiol. Dis. 2, 79-85.

Liu Z, Martin LJ (2003) Olfactory bulb core is a rich source of neural progenitor and stem cells in adult rodent and human. J. Comp. Neurol. 459, 368-391.

Macas J, Nern C, Plate KH, Momma S (2006) Increased generation of neuronal progenitors after ischemic injury in the aged adult human forebrain. J. Neurosci. 26, 13114-13119.

Maiorano D, Lutzmann M, Mechali M (2006) MCM proteins and DNA replication. Curr. Opin. Cell Biol. 18, 130-136.

Mandyam CD, Harburg GC, Eisch AJ (2007) Determination of key aspects of precursor cell proliferation, cell cycle length and kinetics in the adult mouse subgranular zone. Neuroscience 146, 108-122.

Mani N, Khaibullina A, Krum JM, Rosenstein JM (2010) Vascular endothelial growth factor enhances migration of astroglial cells in subventricular zone neurosphere cultures. J. Neurosci. Res. 88, 248-257.

Mendoza-Torreblanca JG, Martínez-Martínez E, Tapia-Rodríguez M, Ramírez-Hernández R, Gutiérrez-Ospina G (2008) The rostral migratory stream is a neurogenic niche that predominantly engenders periglomerular cells: in vivo evidence in the adult rat brain. Neurosci. Res. 60, 289-299.

Middeldorp J, Boer K, Sluijs JA, De FilippisL, Encha-Razavi F, Vescovi AL, Swaab DF, Aronica E, Hol EM (2010) GFAPS in radial glia and subventricular zone progenitors in the developing human cortex. Development 137, 313-321.

Mizuno N, Kokubu H, Sato M, Nishimura A, Yamauchi J, Kurose H, Itoh H (2005) G protein-coupled receptor signaling through $\mathrm{Gq}$ and JNK negatively regulates neural progenitor cell migration. Proc. Natl. Acad. Sci. USA 102, 12365-12370.

Nielsen AL, Jorgensen AL (2004) Self-assembly of the cytoskeletal glial fibrillary acidic protein is inhibited by an isoform-specific $C$ terminus. J. Biol. Chem. 279, 41537-41545.

Nielsen AL, Holm IE, Johansen M, Bonven B, Jorgensen P, Jorgensen AL (2002) A new splice variant of glial fibrillary acidic protein, GFAP epsilon, interacts with the presenilin proteins. J. Biol. Chem. 277, 29983-29991.

Pallari HM, Eriksson JE (2006) Intermediate filaments as signaling platforms. Sci. STKE. 2006, pe53.

Parent JM, Vexler ZS, Gong C, Derugin N, Ferriero DM (2002) Rat forebrain neurogenesis and striatal neuron replacement after focal stroke. Ann. Neurol. 52, 802-813.

Pencea V, Bingaman KD, Freedman LJ, Luskin MB (2001) Neurogenesis in the subventricular zone and rostral migratory stream of the neonatal and adult primate forebrain. Exp. Neurol. 172, 1-16.

Peretto P, Merighi A, Fasolo A, Bonfanti L (1997) Glial tubes in the rostral migratory stream of the adult rat. Brain Res. Bull. 42, 9-21.

Perng MD, Wen SF, Gibbon T, Middeldorp J, Sluijs J, Hol EM, Quinlan RA (2008) Glial fibrillary acidic protein filaments can tolerate the incorporation of assembly-compromised GFAP-delta, but with con- sequences for filament organization and alphaB-crystallin association. Mol. Biol. Cell 19, 4521-4533.

Quinlan RA, Brenner M, Goldman JE, Messing A (2007) GFAP and its role in Alexander disease. Exp. Cell Res. 313, 2077-2087.

Quinones-Hinojosa A, Sanai N, Soriano-Navarro M, Gonzalez-Perez O, Mirzadeh Z, Gil-Perotin S, Romero-Rodriguez R, Berger MS, GarciaVerdugo JM, Alvarez-Buylla A (2006) Cellular composition and cytoarchitecture of the adult human subventricular zone: a niche of neural stem cells. J. Comp. Neurol. 494, 415-434.

Raponi E, Agenes F, Delphin C, Assard N, Baudier J, Legraverend C, Deloulme J-C (2007) S100B expression defines a state in which GFAP-expressing cells lose their neural stem cell potential and acquire a more mature developmental stage. Glia 55, 165-177.

Ravid R, Van Zwieten EJ, Swaab DF (1992) Brain banking and the human hypothalamus-factors to match for, pitfalls and potentials. Prog. Brain Res. 93, 83-95.

Reynolds BA, Rietze RL (2005) Neural stem cells and neurospheresre-evaluating the relationship. Nat. Methods 2, 333-336.

Roelofs RF, Fischer DF, Houtman SH, Sluijs JA, Van Haren W, van Leeuwen FW, Hol EM (2005) Adult human subventricular, subgranular, and subpial zones contain astrocytes with a specialized intermediate filament cytoskeleton. Glia 52, 289-300.

Roy NS, Wang S, Jiang L, Kang J, Benraiss A, Harrison-Restelli C, Fraser RA, Couldwell WT, Kawaguchi A, Okano H, Nedergaard M, Goldman SA (2000) In vitro neurogenesis by progenitor cells isolated from the adult human hippocampus. Nat. Med. 6, 271-277.

Sanai N, Tramontin AD, Quinones-Hinojosa A, Barbaro NM, Gupta N, Kunwar S, Lawton MT, McDermott MW, Parsa AT, Manuel-Garcia VJ, Berger MS, Alvarez-Buylla A (2004) Unique astrocyte ribbon in adult human brain contains neural stem cells but lacks chain migration. Nature 427, 740-744.

Selkoe D, Kopan R (2003) Notch And presinilin: regulated intramembrane proteolysis links development and degeneration. Annu. Rev. Neurosci. 26, 565-597.

Thal DR, Rüb U, Schultz C, Sassin I, Ghebremedhin E, Del Tredici K, Braak $\mathrm{E}$, Braak H (2000) Sequence of Abeta-protein deposition $\mathrm{n}$ the human medial temporal lobe. J. Neuropathol. Exp. Neurol. 59, 733-748.

Thomas LB, Gates MA, Steindler DA (1996) Young neurons from the adult subependymal zone proliferate and migrate along an astrocyte, extracellular matrix-rich pathway. Glia 17, 1-14.

Verwer RW, Sluiter AA, Balesar RA, Baayen JC, Noske DP, Dirven CM, Wouda J, van DamAM, Lucassen PJ, Swaab DF (2007) Mature astrocytes in the adult human neocortex express the early neuronal marker doublecortin. Brain 130, 3321-3335.

Wang X, Fu S, Wang Y, Yu P, Hu J, Gu W, Xu X-M, Lu P (2007) Interleukin-1 $\beta$ mediates proliferation and differentiation of multipotent neural precursor cells through the activation of SAPK/JNK pathway. Mol. Cell. Neurosci. 36, 343-354.

Zhao C, Deng W, Gage FH (2008) Mechanisms and functional implications of adult neurogenesis. Cell 132, 645-660.

\section{Supporting Information}

Additional supporting information may be found in the online version of this article:

Fig. S1 Fluorescent double immunostaining of GFAP- $\delta$ with astrocyte markers in the SVZ.

Fig. S2 Fluorescent double immunostaining of GFAP- $\delta$ (green) with proliferation and stem cell markers (red) in the SVZ of different control donors. 
Fig. S3 GFAP- $\delta$ expression in the olfactory bulb and tract.

Fig. S4 Confocal pictures of GFAP- $\delta$ in neurosphere cultures from post-mortem human brain.

Table S1 Specifications of the antibodies used.

As a service to our authors and readers, this journal provides supporting information supplied by the authors. Such materials are peer-reviewed and may be re-organized for online delivery, but are not copy-edited or typeset. Technical support issues arising from supporting information (other than missing files) should be addressed to the authors. 